Богом'я В.І., Давидов В.С., Доронін В.В., Пліта Л.Л.

\title{
ДЕЯКІ ПИТАННЯ ПІДВИЩЕННЯ БЕЗПЕКИ МОРЕПЛАВСТВА ВЕЛИКОТОННАЖНИХ СУДЕН
}

Результати аналізу існуючих прибережних $i$ портових систем руху суден, суднових $i$ берегових навігаційних систем безпеки плавання, які використовуються при проводиі суден в каналах і на акваторіях портів и гаваней дозволяють зробити висновок про те, щуо існуюча система безпеки плавання не в повній мірі вирішує завдання безпечного плавання великотоннажних суден в складних умовах.

У статті сформульовано об'єктивні причини, що впливають на зростання аварійності суден, особливо великотоннажних, які пов'язані з їх конструктивними $i$ морехідними особливостями, обмеженими можливостями систем безпеки і існуючих систем руху суден. Зроблено висновок про необхідність автоматизаџіі процесів управління, пов'язаних 3 автоматичним переходом функиій управління гвінторульовим комплексом $i$ судновою енергетичною установкою автоматизованої системи управління судном на базі елементів нейронних технологій і штучного інтелекту.

Ключові слова: судно, безпека плавання, людський фактор, великотоннажні судна, аварійні морські подї, нейронні технології, штучний інтелект.

Постановка проблеми. Результати аналізу АМП, існуючих прибережних і портових систем руху суден, суднових і берегових навігаційних систем безпеки плавання, які використовуються при проводці суден в каналах і на акваторіях портів и гаваней дозволяють зробити висновок про те, що існуюча система безпеки плавання не в повній мірі вирішує завдання безпечного плавання великотоннажних суден в складних умовах.

Аналіз останніх досліджень і публікацій з даної тематики в друкованих виданнях і в інтернет ресурсах виявив відсутність комплексних досліджень і публікацій інших авторів по даному напрямку. У наукових дослідженнях і статтях детально не розглядалися такі вкрай важливі для безпеки судноводіння деякі питання стосовно великотоннажних суден, як:

1. Наявність існуючого протиріччя між знанням високоточного місця судна на траєкторії його руху за допомогою спеціальних режимів роботи ГНСС і недостатньо високою точністю контролю положення судна відносно навігаційних небезпек по пеленгам i дистанціям за допомогою суднових РЛС (ЗАРП).

2. Потребує вдосконалення проблема додаткових можливості ЕКНІС по використанню координатного курсору в якості високоточного кутомірно-далекомірного пристрою. В існуючих ЕКНІС не передбачені опції або функції, що дозволяють реалізувати можливості високоточного місця судна для вимірювання напрямків і дистанцій до навігаційних об'єктів;

3. Прогнозування в ECDIS місцезнаходження носа і корми судна на траєкторії руху з урахуванням напрямків і відстаней до небезпечних навігаційних об'єктів, які безперервно змінюються, в тому числі підводних, 3 урахуванням його інерційно-гальмівних характеристик при аварійному пасивному або активному гальмуванні;

4. Облік елементів повороткості судна в ECDIS з урахуванням впливу полюса повороту на поведінку судна в умовах малих глибин прибережного плавання;

5. Підвищення навігаційної інформативності про розташування судна на траєкторії руху на електронній карті, в тому числі носа і корми, шляхом: 
- геометричної візуалізації розміреній судна і смуги руху на великомасштабних планах портів, гаваней і підхідних каналах до них;

-постійного одночасного відображення на електронної карті лінії попередньої прокладки з розрахунковим місцем судна відповідно до плану переходу і фактичної траєкторії руху судна у вигляді лінії шляху поблизу кромки електронної карти і збереженні іiі після зміни масштабу карти;

-перегляд навігаційної обстановки попереду по напрямку руху за допомогою великомасштабного вікна.

Мета статті. Провести системний аналіз основних проблем, пов'язаних з рішенням деяких класичних завдань судноводіння, при плаванні великотоннажних суден в умовах обмеженого простору портів, гаваней і на підхідних каналах до них в складних навігаційних та гідрометеорологічних умовах. Запропонувати деякі шляхи щодо вирішення виявлених проблем шляхом розширення області навігаційних завдань, що вирішуються в ЕКНІС, так як в складних ситуаціях при обмеженому часі на їх аналіз, розрахунки та прийняття єдино правильного рішення судноводієм робляться неприпустимі помилки і промахи, які іноді закінчуються аварійними морськими пригодами і інцидентами.

Викладання основного матеріалу. Проблемам управління великотоннажними суднами в останні роки приділяється все більша увага. Це можна пояснити чисельним зростанням великотоннажних суден і як наслідок досить високим рівнем їх навігаційної аварійності і великими матеріальними збитками від аварій великих суден. Розміри найбільш великих суден виросли в 1,5-2 рази. Довжина таких суден становить до 400 м, ширина більше 55 м, осадка більше 15-20м [5]. Характерною особливістю сучасних контейнеровозів $і$ пасажирських суден є зростання швидкості, яка у деяких контейнеровозів досягає до 33 уз., $\mathrm{i}$ значне збільшення їх парусності. Збільшення габаритів і маси суден, а також швидкостей їх руху позначилися в свою чергу на інерційно-гальмівних характеристиках і маневрених якостях суден. При цьому відносні величини, такі як діаметр циркуляції і гальмівний шлях, виражені в довжинах суден, не зазнали значних змін, проте абсолютні значення цих величин істотно зросли. Так, час вільного гальмування судна водотоннажністю близько 50 тис. т. становить 12-13хв., а гальмівний шлях - більш 4-х миль. При активному гальмуванні таке судно проходить 1,2-1,5 милі за час 5-6 хв.[5].

Сучасним судноводіям доводиться управляти суднами, інерційність яких в порівнянні з 1960 р зросла в середньому в 10 разів. Навігаційне забезпечення безпечного плавання таких суден стає все більш важливим і складним завданням, особливо при плаванні в умовах обмеженого простору портів, гаваней і на підхідних каналах до них в складних навігаційних та гідрометеорологічних умовах. Поява на морських суднах ECDIS і приймачів ГНСC, які дозволили в значній мірі автоматизувати високоточній контроль за місцем розташування суден на траєкторії руху в режими “on-line”, не привела до значного зниження аварійності, пов'язаної з посадками на мілину або підводні рифі, зіткненнями і навалами. Використання функцій: «завдання безпеки», «виявлення поточної небезпечної ізобати і небезпечних об'єктів», а також «автоматичного захоплення і супроводу цілей при накладенні зображення РЛС на ЕК» в існуючих ECDIS , які використовуються при проводці суден в каналах і на акваторіях портів і гаваней, не вирішує в повній мірі завдання безпечного плавання в складних умовах [2].

У зв'язку зі значним зростанням швидкостей, розмірів суден і їх парусності, виникає необхідність в підвищенні точності і оперативності навігаційної інформації, а також впровадженні засобів і систем автоматизації судноводіння, які в складної аварійної ситуації 
мали б можливість автоматично приймати на себе управління судном, так як в деяких умовах, особливо при плаванні в узкостях, поблизу берегів, на акваторіях портів і в районах 3 великою інтенсивністю суднопотоків, судноводій може виявитися нездатним приймати оптимальні рішення в реальному масштабі часу $[3,4]$. Недостовірна або неповна інформація, так само як і несвоєчасна оцінка складної навігаційної обстановки може привести до АМП. Графік кількості АМП у світовому торговельному флоті у 2011-2018p. наведено на рис.1 за результатами досліджень Свропейського агентства з безпеки на морі за 2019p. За попередні 8 років аварійність вантажних суден зросла приблизно до 2 разів, пасажирських до 2,5 разів [1].

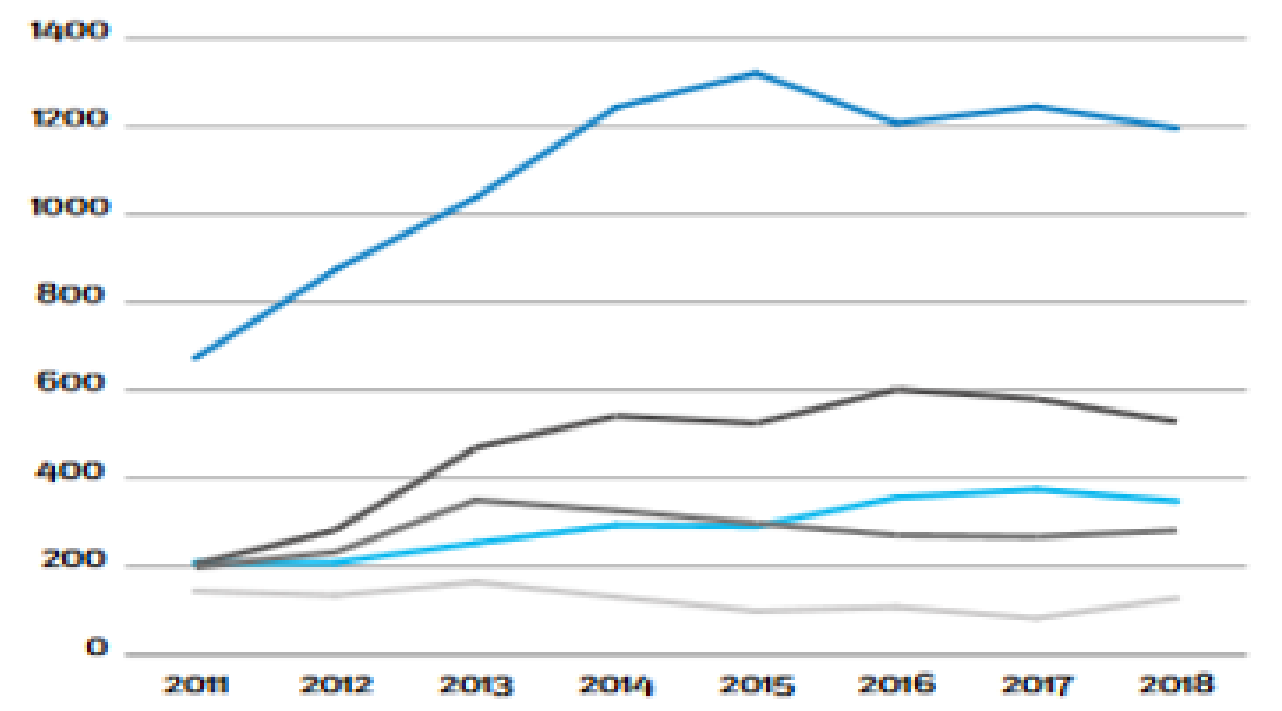

Вантажні судна

Пасажирські судна

Риболовецькі судна Допомінні судна

Інші судна

Рисунок 1- Графік кількості АМП у світовому торговельному флоті у 2011-2018 р.

Для великотоннажних суден зростає вплив на безпеку плавання їх конструктивних особливостей і маневрених характеристик, закладених на стадії проектування:

- великотоннажність суден визначає довгий гальмівний шлях як при пасивному так i активному гальмуванні, який становить тисячі метрів; - значна частина сучасних суден, в першу чергу контейнеровозів, є одновальної, що негативно впливає на їх маневреність та повороткість і з урахуванням дуже великої парусності, особливо контейнеровозів, автомобілевозів і газовозів, а також пасажирських суден. Це призводить до того, що часом при сильному вітри не вистачає зусиль гвінторульового комплексу для утримання суден в заданій смузі на траєкторії руху або на лінії створу.

У таблиці 1 наведені характеристики по 3 типам великотоннажних суден, які найбільшою мірою впливають на їх управління в складних умовах прибережного плавання i служать основним джерелом АМП.

Випереджаюче зростання габаритів великотоннажних суден у порівнянні з ростом портових акваторій і фарватерів створює певні труднощі в експлуатації великотоннажного флоту. 50\% всіх АМП сталося на акваторії портів та рейдах, 10\% - при проходженні шлюзів, $18 \%$-у річках і каналах, 14\% -у протоках і 8\% -у відкритому морі. Якщо врахувати, що час плавання суден у відкритому морі становить більше 90\% у порівнянні з часом плавання в перерахованих вище районах, то 3 розрахунку на 1 ч плавання ймовірність АМП судна в обмежених районах, де майже безперервно здійснюється маневрування, в 10 разів більше, ніж у відкритому морі [5]. 
Невідповідність габаритів існуючих каналів i фарватерів габаритам сучасних великотоннажних суден призводить до того, що в багатьох портах світу і на підходах до них вони обмежені своєю осадкою і розмірами. Це призводить, при плаванні на мілководді, до погіршення керованості і збільшення радіусів циркуляції, які не завжди підлягають точному обліку при плаванні на циркуляції і як наслідок вихід однієї з кінцівок судна за межі смуги руху, що стає причиною торкань грунту і посадок на мілину.

Таблиця 1- Зведена таблиця характеристик великотоннажних суден

\begin{tabular}{|c|c|c|c|c|}
\hline $\begin{array}{l}\text { No } \\
\text { त } \\
/ \\
\text { H }\end{array}$ & Характеристики суден & $\begin{array}{l}\text { Контейнеровози } \\
\text { типу MSC OSCAR } \\
\text { givestiftatg }\end{array}$ & $\begin{array}{c}\text { Пасажирські судна } \\
\text { типу } \\
\text { Oasis of the Seas }\end{array}$ & $\begin{array}{c}\text { Автомобілевози } \\
\text { типу } \\
\text { Hoegh Target }\end{array}$ \\
\hline 1 & Габарити: LxBxH, м & $395,4 \times 59 \times 73$ & $360 \times 47 \times 72$ & $199,9 \times 36,5 \times 80$ \\
\hline 2 & $\begin{array}{l}\text { Площа парусності по } \\
\text { діаметральної площині, кв. м. }\end{array}$ & 22000 & 22400 & 13833 \\
\hline 3 & $\begin{array}{l}\text { Ширина смуги руху для кута } \\
\text { дрейфу на циркуляції } \beta=15^{\circ}\end{array}$ & 142 & 117 & 70 \\
\hline 4 & $\begin{array}{l}\text { Радіус циркуляції на ППХ при } \\
\text { перекладанні керма на кут } \pm 35^{\circ}\end{array}$ & 1325 & 901 & 607 \\
\hline 5 & Кількість гвинтів & 1 & 3 & 2 \\
\hline 6 & $\begin{array}{l}\text { Час/вибіг при активному } \\
\text { гальмуванні пПХ/ПзХ (хв./м.) }\end{array}$ & $12,1 / 3400$ & $5 / 1300$ & $8,9 / 2800$ \\
\hline 7 & $\begin{array}{l}\text { Час/вибіг при пасивному } \\
\text { гальмуванні ППХ/стоП (хв./м.) }\end{array}$ & $24,5 / 9260$ & $22,4 / 8400$ & $20,7 / 7600$ \\
\hline 8 & Осадка (м.) & 16 & 9,3 & 10,3 \\
\hline
\end{tabular}

Габарити и осадка великотоннажних суден у порівнянні з параметрами підхідних каналів, глибинами на акваторіях гаваней і на осях суднових ходів в гирлах припортових річок ростуть випереджальними темпами. Так на 2008p. всього 28 найбільших морських портів світу із 145, яким за даними Американської асоціації портової влади (American Association of Port Authorities) присвоєно статус найбільших портів світу, могли приймати судна з осадкою понад 15м і більше. Як відображено на рис. 2 за 5 років з 2003 р. по 2008 р., які стали періодом різкого зростання будівництва великотоннажних суден, було прийнято в експлуатацію всього 3 глибоководних портів в світі, які здатні приймати судна практично без обмежень.

Через 12 років картина на користь великотоннажних суден змінилася незначно, так як створення глибоководних портів вимагає багато часу i великих капіталовкладень при дефіциті днопоглиблювального флоту в світі в цілому. Дані Lloyd's Register за 2018р.також підтверджують, шо кількість портів в світі, здатних безпечно приймати судна Post-Panamax 3 осадкою 16 м, яка на рухомому в каналі судні ще більше за рахунок просідання, не більше 3 х десятків [6,7]. 


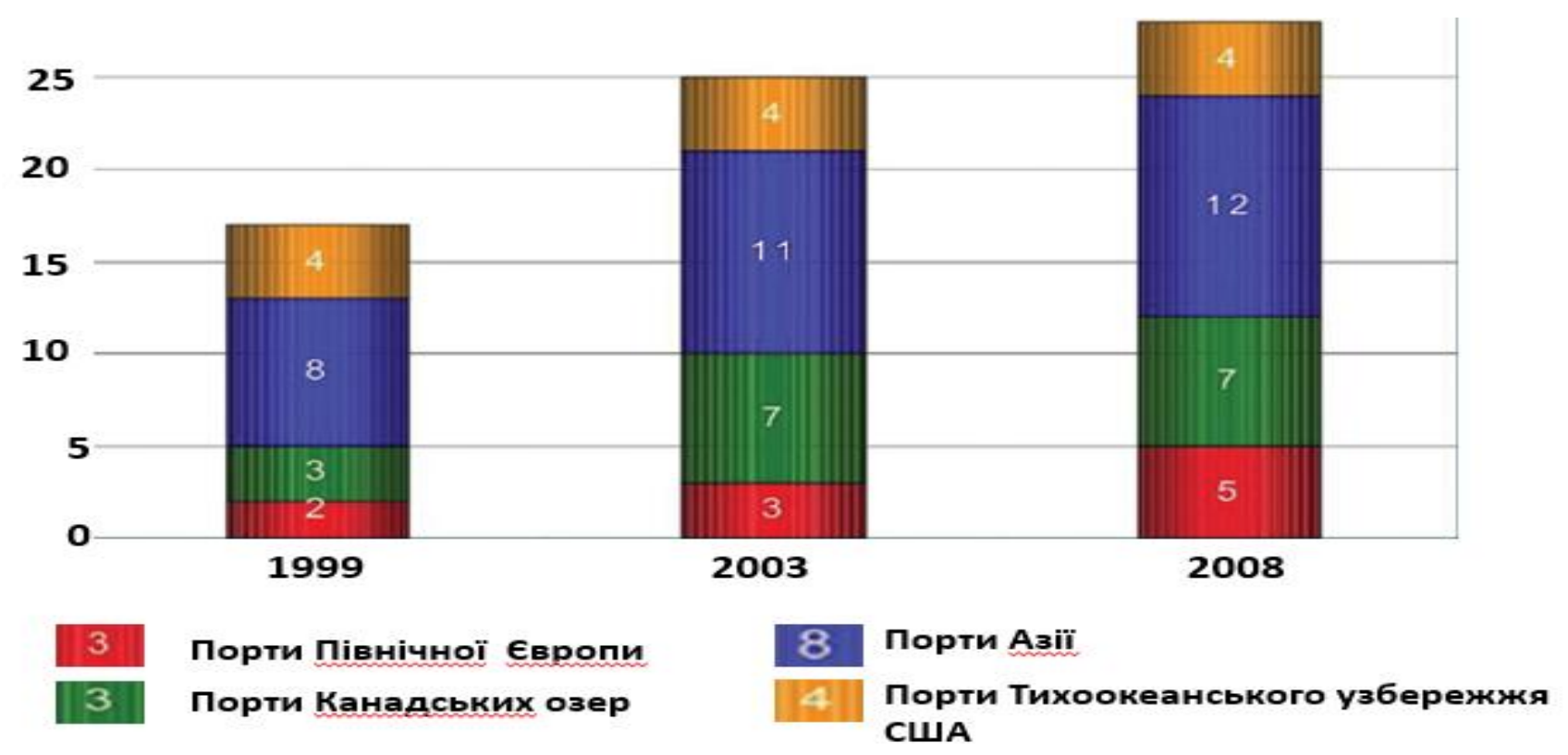

Рисунок 2 - Графік зростання кількості глибоководних портів в світі.

Дизелів обмежень по їх експлуатації (на прикладі дизеля марки MAN B \& W 8K90MCC (Mark 6) потужністю в 36560 кВт або 49742 к. с.):

- мінімальних безпечних критичних обертів які складають 23об/хв; що відповідає швидкості близько 4 вузлів,

- мінімальної швидкості самого малого переднього ходу в 4,6 вузла, яка відповідає 26 об/хв;

- зменшеного до70\% коефіцієнта потужності рушія при роботі на задній хід;

3. Виключно велику парусність великотоннажних суден, яка за площею для пасажирських лайнерів і контейнеровозів дорівнює 3-м стандартним футбольним полям (площа 1-го футбольного поля $\mathrm{S}=7560$ кв. м) що ускладнює утримання судна на осі каналу або суднового ходу;

4. Одногвинтову схему побудови головної енергетичної установки для великовантажних контейнеровозів, що в значній мірі знижує їі надійність і призводить практично до втрати керованості судна при виході з ладу або заклинювання рульового пристрою;

5. Складнощі виведення судна в точку повороту i на нову лінію шляху через неможливість оперативного точного обліку відомими штурманськими способами зміщення полюса повороту і збільшення радіусу циркуляції при плаванні на мілководді при наявності сумарного зносу від вітру і різних видів течій,

На рис.3 наведені значення параметрів циркуляції для порівняно невеликого контейнеровоза типу «Мереда» $(260 x 32 \times 12,6)$ в баласті на глибокій воді при перекладанні керма на кут $\pm 35^{\circ}$ на середньому передньому ходу в 15.4 вузла. Ширина смуги руху становить 83 м. Для контейнеровозів типу MSC OSCAR довжиною 395,4 м. вона становить 142 м., що створює значні труднощі в управлінні судном при поворотах під великим кутом у вузьких каналах і небезпеку торкання кінцівками судна їх кромок.

Для судноводія також важливо спостерігати символ судна на електронній карті у вигляді його силуету в масштабі карти і смугу руху на циркуляції. Це дозволить, при використанні монітора відеопрокладчіка з великою діагоналлю і роздільною здатністю, спостерігати на електронній карті положення свого судна щодо небезпек і проходження їх кінцівками судна. Так на електронній карті-плані М 1:5000 довжина силуету судна 
довжиною 300 м становитиме 6 см. Таке однакове сприйняття реальної обстановки та зображеної на електронній карті дозволяє судноводію швидко орієнтуватися в обстановці при переході від іiі візуального сприйняття до електронного і навпаки, що особливо важливо при раптовому погіршенні видимості.

3 урахуванням обмежень для великотоннажних суден можливостей систем безпеки i існуючих систем руху по параметрам безпечних акваторій і наявності перерахованих вище конструктивних характеристик і обмежень проблема управління великогабаритними судами без використання елементів нейронних технологій і штучного інтелекту представляє з себе складне завдання з багатьма невідомими, алгоритми вирішення яких буде необхідно реалізовувати в ЕКНІС.

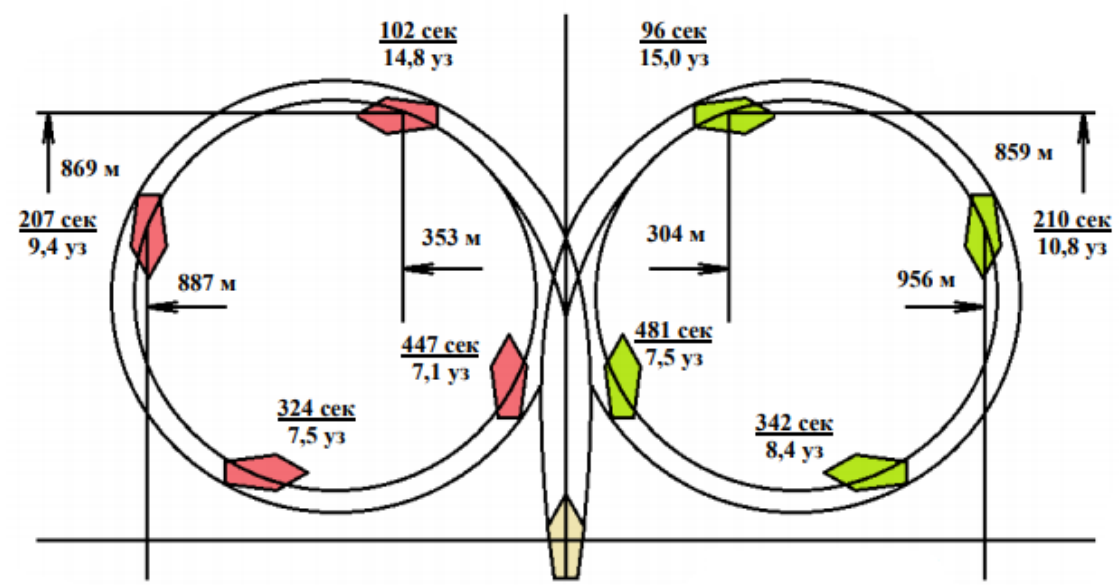

Рисунок 3- Параметри циркуляції контейнеровоза типу «Мереда»

Висновок. На підставі викладеного можна зробити висновок про те що великотоннажні судна необхідно віднести в особливу категорію морських суден, які при плаванні в складних умовах найбільш схильні до АМП і які неправомірно відносити тільки за рахунок впливу «людського фактору». 3 точки зору авторів передумови до їх аварійності закладені в певній мірі в їх конструктивних i морехідних характеристиках і відсутності належного рівня автоматизації процесів управління, пов'язаних 3 автоматичним переходом функцій управління гвінторульовим комплексом i судновою енергетичною установкою автоматизованої системи управління судном на базі елементів нейронних технологій $\mathrm{i}$ штучного інтелекту. Високий професіоналізм судноводіїв та лоцманів великотоннажних суден в складних умовах плавання не завжди може компенсувати їх конструктивні i морехідні особливості та обмеження по експлуатації СЕУ, нездоланні гідрометеорологічні обставини.

\section{ЛIТЕРАТУРА}

1. Annual overview of marine casualties and incidents. // European Maritime Safety Agency. 2019. - C. 21.

2. NAVI - SAILOR 3000. Керівництво користувача, 2002.

3. Давидов В.С. Алгоритм автоматизованого контролю положення кінцівок суден і складів на траєкторії руху засобами ECDIS. Збірник наукових праць ДУIT «Водний транспорт». Вип.1(29), 2020р. С.46-52. Богом'я В.І., Давидов В.С., Доронін В.В., Кудрявцев В.Г. 
4. Давидов В.С. Математична модель забеспечення безпеки плавання буксирніх складів, що штовхаються, на річках і в прибережній морській зоні. Центральний науководослідний інститут озброєння та військової техніки Збройних Сил України. Збірник наукових праць. Вип.3(23) 2019p.,С.117-122. Косяковський А.В., Давидов В.С., Овчіннікова А.І.

5. Давыдов В.С. Анализ некоторых эксплуатационных свойств современных крупнотоннажных судов, методов и систем их обеспечения при плавании в стесненных условиях. К.-КГАВТ, Водний транспорт „Вып.3(21), 2014, С.23-31. Богомья В.И., Давыдов В.С., Кожухаренко Р.В.

6. Список найбільших портів світу [Електронний ресурс]. - 2013.- Режим доступу до pecypcy: https://ru.wikipedia.org/wiki/ Список_крупнейших_портов_мира_(2013).

7. Морські порти світу [Електронний ресурс].- Режим доступу до ресурсу: https://www/searates.com/ru/maritime/

Богомья В.И., Давыдов В.С., Доронин В.В., Плита Л.Л. НЕКОТОРЫЕ ВОПРОСЫ ПОВЫШЕНИЯ БЕЗОПАСНОСТИ МОРЕПЛАВАНИЯ КРУПНОТОННАЖНЫХ СУДОВ.

Результаты анализа эксплуатащии существующих прибрежных и портовых систем движения судов, судового и береговых навигаџионных систем безопасности плавания, которые используют при проводке судов в каналах $и$ в акваториях портов и гаваней позволяют сделать вывод о том, что существующая система безопасности плавания не в полной мере решает задачи безопасного плавания великотоннажних судов в сложных условиях.

Сформулированы объективные причины, влияющие на рост аварийности судов, особенно крупнотоннажных, связанные с их конструктивными и мореходными особенностями, ограниченными возможностями систем безопасности и существующих систем движения судов. Сделан вывод о необходимости автоматизаџии процессов управления, связанных с автоматическим переходом функиий управления винторулевым комплексом и судовой энергетической установкой к автоматизированной системе управления судном на базе элементов нейронных технологий и искусственного интеллекта.

Ключевые слова: судно, безопасность плавания, человеческий фактор, крупнотоннажные суда, аварийные морские происшествия, нейронные технологии, искусственный интеллект.

\section{Bogomia V.I., Davydov V.S., Doronin V.V., Plita L.L. SOME ISSUES OF INCREASING THE SAFETY OF NAVIGATION OF LARGE- TONNAGE VESSELS}

The results of the analysis of the existing coastal and port navigation systems, ship and coastal navigation safety systems, which are used in the conduct of vessels in the canals and waters of ports and harbors allow us to conclude that the existing navigation safety system does not fully solve the problem of safe large-tonnage vessels in difficult conditions.

Objective reasons are formulated that affect the increase in the accident rate of ships, especially large-tonnage ones, associated with their design and seaworthiness, limited capabilities of safety systems and existing ship traffic systems. It is concluded that it is necessary to automate the control processes associated with the automatic transition of the control functions of the rudder complex and the ship's power plant to an automated ship control system based on elements of neural technologies and artificial intelligence.

Key words: ship, navigation safety, human factor, large-capacity vessels, emergency maritime accidents, neural technologies, artificial intelligence. 